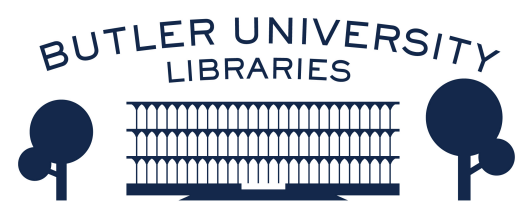

Journal of Hindu-Christian Studies

January 1998

\title{
Book Review: "The Santals, Anthropological-Theological Reflections on Santali and Biblical Creation Traditions"
}

\author{
A. F. Thompson
}

Follow this and additional works at: https://digitalcommons.butler.edu/jhcs

Part of the Religion Commons

\section{Recommended Citation}

Thompson, A. F. (1998) "Book Review: "The Santals, Anthropological-Theological Reflections on Santali and Biblical Creation Traditions"," Journal of Hindu-Christian Studies: Vol. 11, Article 14.

Available at: https://doi.org/10.7825/2164-6279.1187

The Journal of Hindu-Christian Studies is a publication of the Society for Hindu-Christian Studies. The digital version is made available by Digital Commons @ Butler University. For questions about the Journal or the Society, please contact cbauman@butler.edu. For more information about Digital Commons @ Butler University, please contact digitalscholarship@butler.edu. 


\section{Book Reviews}

\section{The Santals, Anthropological-Theological Reflections on Santali and Biblical Creation Traditions. Timotheus Hembrom. Calcutta: Punthi Pustak, 1996, 246 pp. + glossary and bibliography.}

A FRUITFUL AND interesting part of this book is its introduction to the Santals of northern India - probably the largest of Indian aboriginal tribes. A "history" of the Santals through more than 2000 years is attempted with the assistance of anthropologists. Entering upon firmer historical grounds, the book gives eloquent expression to the trials of the Santals during the 19th century, taking account of the attempted and actual inroads of Hinduism, Islam, and Christianity into Santali life. The impact upon the Santals of governance under the Republic of India is also recognized. J. P. Singh is quoted as saying that the Panchayat $R a j$ of the Government of India "has interfered with Santali community life to the extent of destroying cultural values on which their political organizations were based" (p.31).

That traditional social and political organization of the Santals is described by the author, with attention to the respective roles of officials and councils. He gives a succinct account of Santali religious beliefs, and the festivals and ceremonies in which these beliefs find expression.

Against this background, the book proceeds to a comparison of the creation myths of the Santals with those found in the book of Genesis in the Jewish and Christian bible. Both accounts of the beginnings of things were originally orally transmitted; both are found in variant versions. Both are subjected to a scrupulous and exhaustive exegesis and interpretation - which constitutes the largest part of the book.
As the author wished in his Introduction, the result of this scrutiny is likely to be helpful to a Christian understanding of the Santals - and also, perhaps, to a Santali understanding of Christian teaching. "The belief in the creator God has never been a problem with the Santals", he avers, and it is "similar to the belief in the creator God of Genesis 1-3" (p.242).

The study will fall far short of effecting a reconciliation of differing conceptions of creation, however, in part because of its restricted focus - and also in part because of the author's own position. Any Christian teaching about creation cannot be compressed within the first three chapters of Genesis but will be trinitarian in its development. And Dr Hembrom, while he adopts a Christian viewpoint at several points in the text, in his conclusion rejects it, preferring perhaps to stand somewhere between the traditions. "People of scriptures", he writes, "know as little of God as the people of primal religion know about him/her" (p.243).

The author has not been well served by his publisher in two respects. For one, the book abounds in typographical errors. And the book's dustjacket, while attractive, conjures up a stereotype of tribal personality: feathers, earrings, flowing hair, and red eyes proclaim the uninhibited "forest dweller".
A. F. Thompson
Nobel, Ontario 